Paper

\title{
Education for the Gifted and Talented: Student teachers reflecting about autonomy, control, and pedagogical diagnostics in a self-designed workshop program for gifted schoolchildren
}

\author{
David Rott \\ University of Muenster, Germany \\ Correspondence: david.rott@wwu.de
}

Received: 28 February 2019; Accepted: 14 October 2019; Published: 9 November 2019

\begin{abstract}
:
In German schools, gifted education becomes more and more relevant, but it is still rare in universities. University students in teacher education especially have only few opportunities to develop their talents in special programs like honors programs. This paper presents the results of a project in which student teachers designed three workshops on the basis of their own interests and strengths and planned these with school teachers.

To begin with, an overview over the honors programs in Germany is presented. The control and development of pedagogical diagnostics are discussed by a focus group from the perspective of the trainee teachers who developed the workshops for gifted gymnasium (i.e. grammar school) students, including their reflection of the degree of autonomy they experienced. The evaluation data were analyzed by the method of qualitative text analysis (Kuckartz, 2016) with a focus on the categories 'autonomy and control' and 'pedagogical diagnostics.' The central topic is the experience of competence in these fields.
\end{abstract}

Keywords: Trainee teachers; autonomy; pedagogical diagnostics

\section{Introduction}

Honors programs for university students and, in particular, for student teachers are hard to find in Germany. There are two reasons for this:

First, in German history, the term 'Begabung' is connected with National Socialism (Hoyer, Weigand \& Müller-Oppliger, 2013), so there is an equation of gifted education on the one hand and fostering the elites on the other. This equation was shown in particular by institutions like the so-called 'Nationalpolitische Erziehungsanstalten' 
(abbreviated as Napola), in which the Nazis tried to educate the next generation of military leaders. This discourse continued for 70 years after World War II (Hartmann, 2004). Moreover, it seems to be true that, so far, there are few courses on offer attempting to address questions of social inequality. Since the 1980s, gifted education has become a more important topic for schools in both primary and secondary education (Fischer \& Müller 2014). Right now, impulses from educational policy give schools more space to explore gifted education (Bundesministerium für Bildung und Forschung <BMBF> [Federal Ministry of Education and Research], 2018).

Secondly, honors programs for university students in Europe are often extra-curricular (Wolfensberger, 2015) and sometimes integrated into particular programs like grants or organized by foundations (BMBF, 2017).

When looking for university students in teacher education to serve as a target group of honors programs, it is important to be aware of the fact that this group is very diverse. They have different backgrounds and study different subjects at different school types so that the question arose: 'How is it possible to set up and offer a program that fits the group of student teachers?'

This paper discusses workshops that were implemented as a start of an honors program at the University of Muenster designed by student teachers for the students of a secondary school. This evaluation focuses on self-reports of the competences that the student teachers developed under the circumstances outlined above.

The workshops were developed in an obligatory course to be attended by trainee teachers in which they were engaged in gifted education at schools. Four student teachers participating in this course started the development of these workshops to gain insight into gifted education. These workshops combine school enrichment ideas with opportunities universities can offer their students.

Within this small-scale project, it is possible to describe how honors programs can be started in a university where such programs are not the regular form of teaching. Therefore, it was important to look at how the university students evaluated this arrangement and how they described the development of their competences in this field. The evaluation of 'autonomy and control' can give a hint about how university students feel in such a context. Moreover, 'pedagogical diagnostics' is an important point in teacher education which can be developed in such an honors program.

In the following, there will be a short overview of honors programs in Germany (section 2) and a specification of the research question (section 3). The methodological framework will give an insight into the workshops as well as the way in which this study was designed (section 4). Results will be presented in section 5 and discussed in section 6 .

\section{Honors programs in Germany}

There are several definitions of giftedness in educational literature. In this study, giftedness is used in the broad sense of the word. Not only cognitive aspects are relevant for being considered gifted, but there are also socio-emotional aspects and, for example, creativity or 
sensory-motoric aspects that can constitute giftedness. Thus, giftedness is not static but can be developed and should be considered a process. The interaction between a person and the environment is a matter of special importance for evolving giftedness (Fischer, 2014; Heimbach-Steins, 2013; Solzbacher, Schwer \& Doll, 2012).

Universities as well as schools should be places for fostering gifted, motivated, and interested students. There are several aspects which might have to be addressed (Seitz, 2011) without disregarding differences (Hoyer et al., 2013). In higher education, individual fostering of giftedness and talent could be defined as a systematic pedagogical activity of lecturers aiming at fostering students' skills by spotting and acknowledging their resources and potentials, not only looking at their academic attainment but also considering the education of the whole person and her/his developmental potential (Rott, 2017).

In higher education, gifted and talented students can be tutored in special sessions in regular courses or in (extra-curricular) honors programs. 'To be a collegiate honors student implies a higher level of academic achievement than other students as well as the more challenging academic experience that comes with smaller class sizes' (Dailey, 2016, p. 151). In Germany, students may, for example, graduate in teaching German as a foreign language or in intercultural pedagogy and obtain a qualifying certificate (Wolfensberger, 2015).

\section{Research Question}

The overall research question of this paper is: How did the trainee teachers experience their participation in the self-designed workshops with the focus on describing their competence development? The main aspects to be investigated are the topics:

1) autonomy \& control, and

2) pedagogical diagnostics.

Autonomy (Jang, Reeve \& Deci, 2010) is one of the most important aspects (Kingma, HeijnePenninga \& Wolfensberger, 2018) in making honors programs work successfully. Students need to have the freedom to develop their own ideas and projects. Control seems to contradict the idea of autonomy and is linked with the institutions in which this project took place. Universities as well as schools seem to be institutions that limit personal opportunities (e.g. Foucault, 1994). Pedagogical diagnostics is important for trainee teachers' professionalization; later on, they are responsible for identifying the talents and gifts which the students bring to school, and they must teach them in a special way (Vidergor, 2015). The honors programs described here could be a place in which these competences could develop at an early stage of professionalization.

\section{Method}

The workshops are embedded in an accompanying school development research project that has been running since the summer of 2016. The secondary school (Gymnasium) where the workshops took place cooperated with the University of Muenster, aiming at promoting gifted education at this school. At the University of Muenster, the project is linked with educational research seminars (Rott, 2019). The students may also visit schools for observational studies. On the basis of talks with the school teachers, some trainee teachers developed the idea of planning workshops for students aged eleven to fifteen as an educational activity outside the regular classroom. Trainee teachers together with qualified teachers of the schools designed three workshops extending over three days, replacing the 
regular classes in which the students from the participating schools could participate. The topics of the workshops originated from the trainee teachers' interest in fostering the school students' personal development. They decided to choose topics in which they have strengths or special interests. Four trainee teachers took part in this project. They organized three workshops, which ran parallel for three days:

- creating podcasts dealing with themes of personal interest

- adventure-based counseling

- football as a substitute religion

39 students from the school participated in these workshops.

\section{Procedure}

A qualitative research approach was chosen to analyze the trainee teachers' competence development via focus groups, which use the interaction of the participants having the same background to generate data (Flick, 2012; Mäder, 2013). They help to see 'what interviewees think about a concrete theme - what feelings, attitudes, reactions, and doubts they have concerning it - in a situation in which they can contrast their opinion' (Flores \& Alonso, 1995, p. 84). In contrast to single interviews, focus groups can lead to a deeper or broader understanding because there is more interaction amongst the interviewees and they talk about differences and similarities (Macnaghten \& Myers, 2006).

In focus groups, two aspects have to be considered. First, there is a specific topic; and second, all persons taking part must stick to this topic (Flick, 2012). The method is based 'on the therapeutic assumption that people who suffer from a problem will be more inclined to talk to others who share the same problem' (Flores \& Alonso, 1995, p. 85). This is a useful point when conducting an evaluative study like the one at hand.

\section{Participants and collecting data}

All four female trainee teachers took part in the focus group and all of them were in the final stage of their regular studies. All of them took part voluntarily. The meeting of the focus group took 55 minutes. It was recorded and afterwards transcribed. The author of this text was the moderator of the focus group.

The interview guideline attempted to initiate a self-acting talk among the four women who were known to one another because of their participation in the workshops. The opening questions were: 'You all have participated in a three-day-workshop. How did it go? What was your experience?' Some additional questions had been planned in case the focus group did not go well. These questions might concern the learning gains or the differences in comparison with other experiences in academic studies.

\section{Categorization}

The data analysis was performed via Qualitative Text Analysis according to Kuckartz (2016). Therefore, the material was read intensely and the texts were categorized. The resulting categories were connected with special examples which help retracing the empirical work.

\section{Results}

Five categories were used in the analysis, which help to show the students' experience gained in the workshops. 71 codings were set. In this paper, a closer description of the 
categories 'autonomy \& control' and 'pedagogical diagnostics' is given. The other categories are general conditions, relational designs, and diversity of experience which cannot be discussed here due to lack of space. The defining examples are in table 1.

Table 1. Defining examples of codings

\begin{tabular}{|l|l|l|}
\hline Category & Defining examples & $\begin{array}{l}\text { Number } \\
\text { of codings }\end{array}$ \\
\hline $\begin{array}{l}\text { autonomy } \\
\text { and control }\end{array}$ & $\begin{array}{l}\text { Well - this self-reliance in the planning process, that's what I } \\
\text { said - I could do what I wanted to do or what I thought what } \\
\text { was right to do concerning the students. What the students } \\
\text { should learn in these days or what they should adapt and not } \\
\text { what is in the curricula. Or the freedom in planning time and } \\
\text { concerning the contexts. That was pleasant. }\end{array}$ & 13 \\
\hline $\begin{array}{l}\text { pedagogical } \\
\text { diagnostics }\end{array}$ & $\begin{array}{l}\text { In any case I learned - I haven't known the students [from } \\
\text { school] before, one didn't know them at all - that it is } \\
\text { meaningful to know the students while planning such a thing. } \\
\text { For being able to assess them - how their competences are in a } \\
\text { special field for being able to make a better plan - that's what I } \\
\text { take with me out of the project. }\end{array}$ & 17 \\
\hline
\end{tabular}

\section{Autonomy and control}

Autonomy is an important concept students use when describing their experience in the workshops. They mention the execution of their ideas and control by school teachers accompanying the workshops or the project head from university.

The self-reliance concerning the planning processes (see table 1) offers the trainee teachers opportunities for creating their own project. Planning concerns the preparation, the development of one's own goals for the workshops, and questions about the realization of the program with the students attending a school. To say 'I could do what I wanted to do' is even more than that; for, being able to do what a student wants to do means that there are no boundaries or control and influence from the outside. The students can decide what the workshop should look like. The school curricula, which define if and when a topic has to be taught from such a boundary, is not to be found in this project. The freedom of planning and choosing content are also evidence of the freedom of decision-making.

A lack of control does not mean that there is no help if needed, as expressed by a student teacher: 'One could work independently and they gave us credit for creating the workshops. They let us do. But they were there when needed.' The self-reliance is supported by the school teachers trusting in the abilities of their learners. The school children are also not alone and have support if needed. Another point is that the workshops are learning situations without assessments to be conducted by the university students: 'And that ones' [the university students] are not evaluated every time in all these aspects. Concerning content, but also that there was none with us in class or what else.' There are two differences: There is no assessment of the product and there is no 'teacher' monitoring the situation in the classroom. For the trainee teachers, this situation is different from the ones which they usually have to deal with in other projects. 
Concerning evaluation, the trainee teachers added critical comments. Finally, the students taking part in the workshops were to present their results to one another. The teachers wanted to take part in this presentation. 'Looking at this presentation at the end stressed us a bit, because we thought students have to show that they learned something. To be honest that was the only pressure we had. And I caught myself saying 'please don't say 'gaming' that was - maybe one should have sold this in a different way.'

It is not just the students attending a school but also the university students who felt being rated by the teachers. It is important to show that the students learned something and so the presentation became a touchstone for the trainee teachers. 'Gaming,' as used in this context, evokes negative connotations and gives a hint of the appreciation of this performance area. The school students were supposed to learn something; they should not play games in the workshops. Freedom, as described above, gets lost a bit when the expected achievement is in focus. The pressure, experienced by the trainee teachers, is also passed on to the workshop participants, while also affecting all the other school students.

\section{Pedagogical diagnostics}

Pedagogical diagnostics is targeted at university students aiming at planning pedagogical activities. It is process-driven and includes personal development as well as changing the activities of learning groups and individual learners. Pedagogical diagnostics helps teachers find a flexible way of teaching. In the program, the university students did not know the participants beforehand: 'What was difficult, I guess, was not knowing the students [of the school] and that one was not able to guess: Have they heard about pedagogics? Do they have any experience in this field? Or that it's difficult to deal with it or that what we planned it's too easy for them.'

It is obvious that there is a gap between the planning of the workshops and the knowledge level of the school participants. The university students are not able to assess their prior knowledge or how to integrate their suggestions. That is where the success of the project depends on the level of difficulty of the tasks. The trainee teachers were not sure if the plan would be welcomed and if it would be feasible. During the workshop, the trainee teachers have to modify and adapt their procedures.

Another element is scheduling: 'The time scheduling was tough to call - some school students were working fast and finished after the fourth lesson, but some were slower and needed up to the sixth lesson.' This means that the school students make use of the structure of the workshops in different ways and that they require different lengths of time to finish their products.

The uncertainty of the school students working in the workshops stands in contrast to how they managed to progress during the project: 'That was very positive, because one didn't know - and that was an inhibition threshold at the beginning - and a little bit of anxiety - if it would really work - but they [the school students] reacted so positively. They were supermotivated. They reacted well. Just right at the first day we were surprised how well it worked. That was a good experience. To see how the students were engaged in what we wanted them to do.' "Inhibition threshold" and "anxiety" refer to trainee teachers' 
insecurity right at the start of the workshops. However, the reaction given by the students concerning the workshops was positive afterwards and helped clearing the worries that the trainee teachers had had. The school students are described as motivated participants and the trainee teachers experienced that their plans worked.

The university students evaluated their workshops via the feedback of the school students. They focused on what the students had learned in the workshops. 'Well, it was awesome that they really took away things from the workshops. I was open-mouthed that they used so much.' The university students were astonished at what the school students said they had learned in the workshops. It seems to be more than had been expected.

The university students described their increase of competence in the area of pedagogical diagnostics when they talked about how important it is to know the students whom one is working with when adapting the activities of the workshop. 'In every case I learned that it is important to know the students when planning something like the workshop. That helps assessing their competence and skills in specific areas. In addition, it helps planning the time schedule. That's what I gained from the program.'

\section{Discussion}

How did the trainee teachers experience their participation in a series of self-designed workshops focusing on their descriptions of competence development? That is the core question. As the results, presented above, show, the university students' evaluation of the workshops can be classified as nuanced, showing how complex extra-curricular activities are. Considering autonomy and control, there is a need for balance. On the one hand, university students need a structure in which they can develop something; on the other, they require orientation as well as space for their development. The trainee teachers can be given an ongoing experience by conducting the workshops concerning pedagogical diagnostics. These could be useful looking into in respect to their future as teachers. Central aspects of diagnostics were discussed in the focus group.

The university students had the opportunity to position themselves and to describe their personal development. The self-reports were compiled in a social way because of the discussion in the focus group, which helped the students to review their experience in a critical way.

Concerning honors programs in Germany one could ask if programs like the workshops could be a starting point. There are only a few trainee teachers who can be reached with such a program. In a systematic way, it seems to be important to develop more ideas of this sort.

In the interest of teacher education, it would be a good idea to have more projects like the workshops discussed in this paper. Trainee teachers need to deal with students and colleagues later on. Honors programs could be a starting point to explore the field of practice in a specific way.

Further research should consider the schoolchildren and how they experience these workshops conducted by university students. The teachers in schools supporting such a project should also be integrated into the evaluation. The university teachers should be part of the evaluation, too. But, this seems to be realistic only when more programs of this sort are performed and more university teachers are involved. 


\section{References}

Bundesministerium für Bildung und Forschung (BMBF) (2017). Mehr als ein Stipendium. Retrieved from: https://www.bmbf.de/pub/Mehr_als_ein_Stipendium.pdf. (accessed 27 November 2018)

Bundesministerium für Bildung und Forschung (BMBF) (BMBF) (2018). Leistung macht Schule. Retrieved from: https://www.bmbf.de/de/leistung-macht-schule-3641.html. (accessed 27 November 2018)

Dailey, R. (2016). Honors Teachers and Academic Identity: What to Look For When Recruiting Honors Faculty. Journal of the National Collegiate Honors Council - Online Archive, 520, 151188.

https://digitalcommons.unl.edu/cgi/viewcontent.cgi?article=1512\&context=nchcjournal

Fischer, C. (2014). Individuelle Förderung als schulische Herausforderung. Bonn: Bonner Universitäts-Buchdruckerei.

Fischer, C. \& Müller, K. (2014). Gifted education and talent support in Germany. CEPS Journal, 4, (3) 31-54.

Flick, U. (2012). Qualitative Sozialforschung. Eine Einführung. Reinbek bei Hamburg: Rowohlt Taschenbuch Verlag.

Flores, J. \& Alonso, C. (1995). Using Focus Groups in Educational Research. Exploring Teachers' Perspectives on Educational Change. Evaluation Review 19(1), 84-101. http://journals.sagepub.com/doi/pdf/10.1177/0193841X9501900104.

Foucault, M. (1994). Überwachen und Strafen. Die Geburt des Gefängnisses. Frankfurt am Main: Suhrkamp.

Hartmann, M. (2004). Elitensoziologie. Frankfurt am Main: Campus Verlag.

Heimbach-Steins, M. (2013). Gerechte Bildungschancen für alle? Defizite, Kriterien, Ansätze. In: Fischer, C. (Ed.), Schule und Unterricht adaptiv gestalten: Fördermöglichkeiten für benachteiligte Kinder und Jugendliche. (p. 35-60). Münster: Waxmann.

Hoyer, T., Weigand, G. \& Müller-Oppliger, V. (2013). Begabung. Eine Einführung. Darmstadt: Wissenschaftliche Buchgesellschaft.

Jang, H., Reeve, J., \& Deci, E. L. (2010). Engaging students in learning activities: It is not autonomy support or structure but autonomy support and structure. Journal of Educational Psychology, 102 (3), 588. doi:10.1037/a0019682. 
Kingma, T., Heijne-Penninga, M., \& Wolfensberger, M. (2018). "Offering freedom" as teaching strategy for honors students. Journal of the European Honors Council, 2(1), 5. https://doi.org/10.31378/jehc.7

Kuckartz, U. (2016). Qualitative Inhaltsanalyse- Methoden, Praxis, Computerunterstützung. Weinheim: Beltz Juventa.

Macnaghten, P. \& Myers, G. (2006). Focus Groups. In: Seale, C., Gobo, G., Gubrium, J. \& Silverman, D. (Eds.), Qualitative Research Practice (p. 65-79). London: Sage Publications.

Mäder, S. (2013). Die Gruppendiskussion als Evaluationsmethode - Entwicklungsgeschichte, Potenziale und Formen. Zeitschrift für Evaluation, 12 (1), 23-51.

Rott, D. (2017). Die Entwicklung der Handlungskompetenz von Lehramtsstudierenden in der individuellen Begabungsförderung. Forschendes Lernen aufgezeigt am Forder-Förder-Projekt Advanced. Münster: Waxmann.

Rott, D. (2019). Partizipation und Kompetenzorientierung - ein Widerspruch? Überlegungen zum Seminar ,Fragen einer diversitätssensiblen Schul- und Unterrichtsentwicklung'. In: Baar, R., Feindt, A. \& Trostmann, S. (Eds.), Lernwerkstätten als pädagogisch-didaktischer Lern- und Erfahrungsraum. Potential und Herausforderung für Lehrerbildung und

kindheitspädagogische Studiengänge (p. 254-264). Bad Heilbrunn: Klinkhardt.

Seitz, S. (2011). Eigentlich nichts Besonderes - Lehrkräfte für die inklusive Schule ausbilden. Zeitschrift für Inklusion (3). Retrieved from: http://www.inklusiononline.net/index.php/inklusion/article/view/124/122 (accessed 29 June 2018)

Solzbacher, C., Schwer, Ch. \& Doll, I. (2012). Individuelle Förderung als Begabungsförderung. In: Solzbacher, C., Müller-Using, S. \& Doll, I. (Eds.), Ressourcen stärken! Individuelle Förderung als Herausforderung für die Grundschule (p. 19-28). Köln: Link.

Vidergor, H. E. (2015). Who is the Best Teacher of Gifted and Able Students? In: Vidergor, H.E. \& Harris, C.R. (Eds.), Applied Practice for Educators of Gifted and Able Learners. (p. 4355). Rotterdam: Sense Publishers.

Wolfensberger, M. V. C. (2015). Talent Development in European Higher Education. Honors programs in the Benelux, Nordic and German-speaking countries. Wiesbaden: Springer. https://link.springer.com/book/10.1007/978-3-319-12919-8 